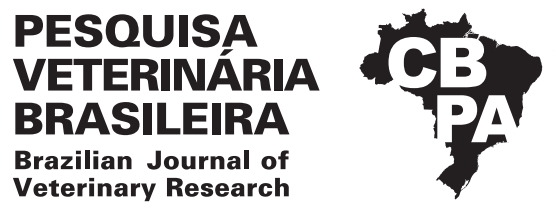

Pesq. Vet. Bras. 38(11):2150-2154, novembro 2018 DOI: 10.1590/1678-5150-PVB-5633

Original Article

Animais Selvagens/Wildlife Medicine

ISSN 0100-736X (Print)

ISSN 1678-5150 (Online)

\title{
Antimicrobial susceptibility and diarrheagenic diagnosis of Escherichia coli and Salmonella enterica isolated from feral pigeons (Columba livia) captured in Fortaleza, Brazil ${ }^{1}$
}

\author{
Ruben V. Horn ${ }^{2 *}$, Windleyanne G.A. Bezerra², Elisângela S. Lopes², \\ Régis S.C. Teixeira ${ }^{2}$, Isaac N.G. Silva ${ }^{2}$, Mariana D. Bona ${ }^{3}$, Alexandre Havt ${ }^{3}$ \\ and William M. Cardoso ${ }^{2}$
}

\begin{abstract}
Horn R.V., Bezerra W.G.A., Lopes E.S., Teixeira R.S.C., Silva I.N.G., Bona M.D., Havt A. \& Cardoso W.M. 2018. Antimicrobial susceptibility and diarrheagenic diagnosis of Escherichia coli and Salmonella enterica isolated from feral pigeons (Columba livia) captured in Fortaleza, Brazil. Pesquisa Veterinária Brasileira 38(11):2150-2154. Laboratório de Estudos Ornitológicos, Faculdade de Veterinária, Universidade Estadual do Ceará, Av. Paranjana 1700, Fortaleza, CE 60740-000, Brazil. E-mail: rubenhorn@hotmail.com

This study aimed to isolate Escherichia coli and Salmonella enterica from captured feral pigeons in Fortaleza, Brazil, and, in addition to evaluate the antimicrobial susceptibility profiles and diagnose diarrheagenic E. coli strains. Pigeons were captured in four public locations in Fortaleza with three techniques. Individual cloacal swab samples were collected and submitted to bacterial isolation, biochemical identification and antimicrobial susceptibility test. Disk diffusion technique was used with twelve antibiotics. E. coli strains were submitted to DNA extraction followed by PCR to diagnose five diarrheagenic pathotypes. A total of 124 birds were captured. One bird was positive for Salmonella enterica $(0.81 \%)$ and $121(97.58 \%)$ were positive for E. coli. Among these, 110 isolates were submitted to antimicrobial susceptibility test and $28.18 \%(31 / 110)$ presented resistance to at least one antibiotic. Resistance to azithromycin was the most frequent $(21.82 \%)$, followed by tetracycline $(10.91 \%)$ and sulfamethoxazole with trimethoprim (8.9\%). Multidrug resistance, calculated as a resistance to at least 3 antimicrobial classes, was identified in 3.64\% (4/110) of strains. The maximum number of antimicrobial classes to which one strain was resistant was seven. Results demonstrated nine different resistance profiles and the most frequent was tetracycline and sulfamethoxazole with trimethoprim (4 strains), followed by chloramphenicol, azithromycin, tetracycline and sulfamethoxazole with trimethoprim (3 strains). Amoxicillin with clavulanic acid and tobramycin presented lowest levels of antimicrobial resistance, to which none of the tested strains were resistant. A single strain was positive for the eltB gene, which is a diagnostic tool to identify the Enterotoxigenic E. coli (ETEC) pathotype. None of the other investigated genes (stx1, stx2, estA, eaeA, ipaH, aatA and aaiC) were identified. The single isolate of $S$. enterica was a rough strain of Salmonella enterica subsp. enterica, but serotype identification was not possible. However, this isolate presented resistance to amoxicillin, amoxicillin with clavulanic acid, tetracycline and sulfamethoxazole with trimethoprim. Therefore, captured feral pigeons of Fortaleza presented a low prevalence of S. enterica and diarrheagenic E. coli. Considering
\end{abstract}

\footnotetext{
${ }^{1}$ Received on February 20, 2018.

Accepted for publication on June 3, 2018.

${ }^{2}$ Post-Graduate Program in Veterinary Science, Laboratório de Estudos Ornitológicos, Faculdade de Veterinária, Universidade Estadual do Ceará
}

(UECE), Avenida Silas Munguba 1700, Fortaleza, CE 60740-000, Brazil. ${ }^{*}$ Corresponding author: rubenhorn@hotmail.com

${ }^{3}$ Laboratório de Toxinologia Molecular, Faculdade de Medicina, Universidade Federal do Ceará, Rua Alexandre Baraúna 949, Fortaleza, CE 60430-160. 
the investigated pathogens, our results suggest a good health status and a low public health risk. However, important antimicrobial resistance profiles were identified.

INDEX TERMS: Antimicrobial susceptibility, diarrheagenic diagnosis, Escherichia coli, Salmonella enterica, feral pigeons, Fortaleza, Brazil, rock pigeon, multidrug resistance, wild birds.

RESUMO-- [Isolamento, sensibilidade antimicrobiana e
diagnóstico de cepas diarreiogênicas de Escherichia coli
e Salmonella enterica isoladas de pombos urbanos
(Columba livia) capturados em Fortaleza, Brasil.] O objetivo deste estudo foi isolar cepas de Escherichia coli e Salmonella enterica de pombos urbanos capturados em Fortaleza, Brasil, e avaliar os perfis de resistência antimicrobiana dos isolados, bem como diagnosticar patotipos diarreiogênicos de E. coli. Pombos foram capturados em quatro locais públicos de Fortaleza utilizando três técnicas. Amostras individuais de suabes cloacais foram coletadas e submetidas a isolamento bacteriano, seguido de identificação bioquímica e teste de susceptibilidade a antimicrobianos. A técnica de disco difusão foi utilizada para avaliar resistência antimicrobiana a doze antibióticos. Cepas de E. coli foram submetidas à extração de DNA seguido de PCR para o diagnóstico de cinco patotipos diarreiogênicos. Um total de 124 aves foram capturadas, a partir das quais em uma houve isolamento de Salmonella enterica $(0,81 \%)$ e em $121(97,58 \%)$ houve isolamento de E. coli. Destas, 110 isolados foram submetidos a teste de suscetibilidade a antimicrobianos e 28,18\% (31/110) apresentaram resistência a pelo menos um antibiótico. Resistência a azitromicina foi a mais frequente $(21,82 \%)$, seguida por tetraciclina $(10,91 \%)$ e sulfametoxazol com trimetoprim $(8,9 \%)$. Resistência a múltiplas drogas foi identificada em 3,64\% (4/110) dos isolados e o número máximo de antibióticos aos quais uma única cepa foi resistente foi sete. Resultados demonstraram nove diferentes perfis de resistência e o mais frequente foi tetraciclina e sulfametoxazol com trimetoprim (4 cepas), seguido por cloranfenicol, azitromicina, tetraciclina e sulfametoxazol com trimetoprim (3 cepas). Amoxicilina com ácido clavulânico e tobramicina foram os antibióticos com menor resistência antimicrobiana, aos quais nenhuma cepa apresentou resistência. Uma única cepa foi positiva para o gene eltB que é usado para diagnóstico do patotipo E. coli enterotoxigênica (ETEC), enquanto que os demais genes investigados (stx1, stx2, estA, eaeA, ipaH, aatA e aaiC) não foram identificados. A única cepa de $S$. enterica isolada foi identificada como uma cepa rugosa de Salmonella enterica subsp. enterica e, portanto, a identificação do sorotipo não foi possível. Entretanto, este isolado apresentou resistência a amoxicilina, amoxicilina com ácido clavulânico, tetraciclina e sulfametoxazol com trimetoprim. Portanto, pombos urbanos capturados em Fortaleza apresentaram baixa prevalência de cepas de S. enterica e E. coli diarreiogênicas. Considerando os patógenos investigados, os resultados encontrados sugerem um bom status sanitário destas aves e um baixo risco à saúde pública. Entretanto, importantes perfis de resistência antimicrobiana foram identificados.

TERMOS DE INDEXAÇ̃̃̃: Antimicrobiana, diagnóstico diarreiogênicas, Escherichia coli, Salmonella enterica, pombos urbanos, Fortaleza, Brasil, pombo das rochas, resistência a múltiplas drogas, aves selvagens.

\section{INTRODUCTION}

Feral pigeons (Columba livia) have adapted to the urban environment and populations are now widespread in several countries (Morabito et al. 2001, Pedersen et al. 2006, Dutta et al. 2013b), including Brazil (Silva et al. 2009). In some locations, increasing populations have been reported and control measures have been applied, such as in Chile, in which this avian species was considered a plague (González-Acuña et al. 2007). These birds can host several human pathogens and a total of 60 have already been identified, including protozoa, bacteria, viruses and fungi (Haag-Wackernagel \& Moch 2004). Among these, different serotypes of the genus Salmonella have been isolated from these animals, raising concern for the public health in several locations.

Salmonella enterica is a species of Gram-negative bacteria, member of the Enterobacteriaceae family, and over 2,500 different serotypes have been identified. Some of these are species-specific, while many others may infect multiple hosts, including humans (Grimont \& Weill 2007). Several reports show that these microorganisms are frequently isolated from feral pigeons in different countries (Refsum et al. 2002, Dovč et al. 2004, Sousa et al. 2010, Dutta et al. 2013a, Osman et al. 2013). However, there is a great variation between prevalence values in these reports and which serotypes are found. In addition, there is considerable effort employed by the scientific community to understand the dispersal of this pathogen among these hosts.

Another aspect of concern related to microorganisms isolated from feral pigeons is antimicrobial resistance. This is a matter of concern for the public health worldwide for limiting therapeutic options in infectious cases. The increase of resistance in human pathogens is frequently related to food producing animals and Escherichia coli is often used as an indicator in different studies (EFSA \& ECDC 2016). However, free-living birds may host resistant strains and this microbial species is frequently isolated from feral pigeons with variable levels of antimicrobial resistance (Silva et al. 2009, Dutta et al. 2013b). In addition, considering that, diarrheagenic E. coli strains have been isolated from feral pigeons (Morabito et al. 2001, Gargiulo et al. 2014), the proximity of these birds with humans could be a risk for the public health. Therefore, this study aimed to isolate and evaluate antimicrobial resistance of Salmonella enterica and Escherichia coli strains from feral pigeons (Columba livia) captured in Fortaleza, Brazil.

\section{MATERIALS AND METHODS}

Ethics statement. This project was authorized by the Brazilian Institute of the Environment and Renewable Natural Resources (IBAMA) with the following protocol number: 47316-1. In addition, this study was submitted and approved by the local Ethics Committee for the Use of Animals of the State University of Ceará with the following protocol number: 2081925.

Capture. From November 17, 2014 to June 14, 2015, feral pigeons were captured in four locations in Fortaleza, the Capital 
city of the State of Ceará - Brazil. Two locations (A: $3^{\circ} 43^{\prime} 45.5^{\prime \prime} \mathrm{S}$ $38^{\circ} 31^{\prime} 35.1^{\prime \prime} \mathrm{W}$; B: $3^{\circ} 44^{\prime} 24.0^{\prime \prime} \mathrm{S} 38^{\circ} 31^{\prime} 28.9^{\prime \prime} \mathrm{W}$ ) were public squares in which pigeons were found in large quantities in close contact with humans. The other two locations (C: $3^{\circ} 47^{\prime} 43.4^{\prime \prime} \mathrm{S} 38^{\circ} 33^{\prime} 30.0^{\prime \prime} \mathrm{W}$; D: $3^{\circ} 46^{\prime} 31.4^{\prime \prime} \mathrm{S} 38^{\circ} 32^{\prime} 49.7^{\prime \prime} \mathrm{W}$ ) were places in which pigeons are not used to the human presence. Three different techniques were used based on the location and behavior of the birds, which were: net throwing, tomahawk trapping and a noose carpet was built. Noose carpet trap is a variation of the Bal-Chatri technique and was prepared with nooses tied to a $1 \mathrm{~m}^{2}$ wired frame using corn as bait in the middle. Net throwing technique was used in locations in which pigeons were accustomed to humans, allowing an approach necessary for successfully throwing the net. In these locations, early in the morning, before pedestrian activity initiated, corn was thrown as bait and when an adequate amount of birds were within a distance of at least $2 \mathrm{~m}$ the net was thrown. Noose carpets and tomahawk traps were used in the locations in which pigeons did not tolerate well the human presence, often flying away at a minimum distance of $15 \mathrm{~m}$. In these locations, from $8 \mathrm{~h}$ a.m. to $4 \mathrm{~h}$ p.m. traps were placed with corn as bait and observed in intervals of $15 \mathrm{~min}$ for removing trapped birds. Once captured, individual cloacal swab samples were collected and immediately submitted to microbiological procedure. Pigeons that died in traps were submitted to necropsy and representative fragment samples were collected aseptically from liver, spleen and intestines for bacteriological procedure.

Microbiological procedure. For the isolation of Escherichia coli, cloacal swabs and organ samples were placed in tubes containing $10 \mathrm{~mL}$ of $0.1 \%$ buffered peptone water and incubated. Then, a loopful was collected from each tube and streaked in Eosin Methylene Blue agar plate (EMB). After incubation colonies with morphological characteristics of $E$. coli were collected and submitted to biochemical identification with the following tests: triple-sugar-iron agar (TSI), sulfide-indole-motility agar (SIM), lysine iron agar (LIA), methyl red production, Voges-Proskauer, malonate and citrate. Isolates confirmed as Escherichia coli were maintained in nutrient agar for antimicrobial susceptibility test. For the isolation of Salmonella enterica, the guidelines of the normative instruction 62 of the Brazilian Ministry of Agriculture, Livestock and Supply (Ministério da Agricultura Pecuária e Abastecimento, MAPA) were followed with some modifications. From the tubes containing buffered peptone water, after incubation aliquots of $0.1 \mathrm{~mL}$ and $1 \mathrm{~mL}$ were collected from each sample and transferred to the selective enrichment step. This step was performed with tubes containing the broths Rappaport-Vassiliadis and Selenite-Cystine added novobiocin $0.4 \mu \mathrm{g} / \mathrm{mL}$, respectively, which were then incubated. Then, a loopful from each broth was streaked in plates containing brilliant green agar added novobiocin $0.4 \mu \mathrm{g} / \mathrm{mL}$ and Salmonella-Shigella agar. After incubation, colonies suggestive of $S$. enterica were selected and submitted to a screening with the biochemical tests: TSI, LIA, SIM and urease production. The isolates with biochemical profile suggestive of Salmonella enterica were confirmed with rapid slide agglutination test performed with polyvalent Salmonella sp. antisera. Positive samples were cultured in nutrient agar and sent to the Laboratory of Enterobacteria of the Oswaldo Cruz Institute Foundation (LABENT-FIOCRUZ) for serotype identification. All of the incubation steps were performed at $37^{\circ} \mathrm{C}$ for $24 \mathrm{~h}$ in bacteriological incubator.

Antimicrobial susceptibility test. The $S$. enterica and Escherichia coli strains isolated in this study were submitted to antimicrobial susceptibility testing using the disk diffusion method. After incubation in Mueller-Hinton agar plates at $37^{\circ} \mathrm{C}$ for $24 \mathrm{~h}$, inhibition zones around the antimicrobial disks were measured and compared to the standards provided by CLSI (2014). Intermediate results were interpreted as resistant. Disks containing the following antimicrobials and concentrations were used: amoxicillin $(10 \mu \mathrm{g})$, amoxicillin with clavulanic acid $(20 / 10 \mu \mathrm{g})$, cephalexin $(30 \mu \mathrm{g})$, ceftiofur $(30 \mu \mathrm{g})$, ciprofloxacin $(5 \mu \mathrm{g})$, sulfamethoxazole with trimethoprim $(25 \mu \mathrm{g})$, polymyxin B (300I.U.), gentamycin $(10 \mu \mathrm{g})$, tobramycin $(10 \mu \mathrm{g})$, chloramphenicol $(30 \mu \mathrm{g})$, tetracycline $(30 \mu \mathrm{g})$ and

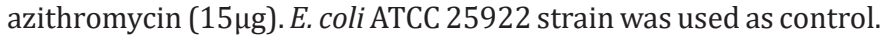

Diarrheagenic Escherichia coli. DNA was extracted from the E. coli isolates and were submitted to polymerase chain reaction (PCR) to diagnose five diarrheagenic pathotypes. Briefly, isolates were inoculated in BHI broth, incubated and plated on MacConkey agar plates. Then, three colonies of each isolate were collected and submitted to a simple extraction method. Colonies were placed in tubes with $1 \mathrm{~mL}$ of Triton $\mathrm{X}-100$, boiled for $20 \mathrm{~min}$ at $94^{\circ} \mathrm{C}$, followed by centrifugation at $10.000 \mathrm{rpm}$ for $10 \mathrm{~min}$. After this procedure, the supernatant was collected, quantified by spectrophotometry and used as DNA sample for the reaction. The GoTaq Green Master Mix ${ }^{\circledR}$ kit (Promega, São Paulo, Brazil) was used for the PCR in a total volume of $20 \mu \mathrm{L}$ per reaction with the following protocol: $95^{\circ} \mathrm{C}$ for $5 \mathrm{~min}$; 40 cycles of $95^{\circ} \mathrm{C}$ for $30 \mathrm{~s}, 57^{\circ} \mathrm{C}$ for $30 \mathrm{~s}$ and $72^{\circ} \mathrm{C}$ for $1 \mathrm{~min}$. Finishing the PCR, samples were heated at $72^{\circ} \mathrm{C}$ for $10 \mathrm{~min}$. The following genes were used to diagnose the diarrheagenic pathotypes: genes stx1 (348pb) and stx2 (584pb) for the identification of Shiga-Toxin producing E. coli (STEC); eltB (508pb) and est $A(147 \mathrm{pb})$ for enterotoxigenic E. coli (ETEC); eaeA (881 pb) for enteropathogenic E. coli (EPEC); ipaH (483 pb) for enteroinvasive E. coli (EIEC); aatA $(630 \mathrm{pb})$ and aaiC $(215 \mathrm{pb})$ for enteroaggregative E. coli (EAEC) (Taniuchi et al. 2012). Reference strains EAEC 042, EHEC 0157:H7, EIEC 0124, EPEC 2348/69 and ETEC H10407 were used as positive controls for the reactions. Amplified products were submitted to $2 \%$ agarose gel electrophoresis stained with ethidium bromide and photo documented using Chemidoc XRS System (Bio-Rad Laboratories).

\section{RESULTS}

Captured birds. In public squares, pigeons were successfully captured with the net throwing technique, while noose carpets and tomahawk traps were used in the other two locations. A total of four birds died in noose carpets, three asphyxiated between the $15 \mathrm{~min}$ intervals of observation, and one was predated by a raptor (Southern Caracara, Caracara plancus) while trapped. Necropsied birds were positive for Escherichia coli only in samples collected from intestine, which were accounted and processed equally as the cloacal swab samples. No E. coli or S. enterica was isolated from samples collected from extra-intestinal organs and no macroscopic lesions were identified in the necropsies. Most pigeons were collected in location $B(n=34)$, followed by $C(n=31), A(n=30)$ and D $(n=29)$. A total of 124 birds were captured and 121 were positive for E. coli (97.58\%). A single strain of $S$. enterica was isolated from samples $(0.81 \%)$ and was identified as a rough strain of Salmonella enterica subsp. enterica.

Antimicrobial resistance. Among the E. coli isolates, 110 were submitted to antimicrobial susceptibility tests. In storage, 11 strains were lost and were not submitted to further tests. The antibiotic to which strains presented the most frequent resistance was azithromycin (21.82\%), followed by tetracycline (10.91\%) and sulfamethoxazole with trimethoprim (8.9\%) (Table 1). Considering the 110 strains that were tested, $28.18 \%(31 / 110)$ presented resistance to at least one antibiotic. 
Multidrug resistance, calculated as a resistance to at least 3 antimicrobial classes, was identified in $3.64 \%(4 / 110)$ of strains. A total of 9 different resistance profiles was identified and the most frequent was tetracycline and sulfamethoxazole with trimethoprim (4 strains), followed by chloramphenicol, azithromycin, tetracycline and sulfamethoxazole with trimethoprim ( 3 strains). The maximum number of antibiotic classes to which a strain presented resistance was 7 (1 strain), followed by 5 ( 1 strain) (Table 2). Amoxicillin with clavulanic acid and tobramycin were the most effective antibiotics, to which none of the analyzed strains presented resistance. The S. enterica isolate was resistant to four antibiotics with the following profile: amoxicillin, amoxicillin with clavulanic acid, tetracycline and sulfamethoxazole with trimethoprim.

Table 1. Antimicrobial resistance rates obtained from 110 Escherichia coli strains isolated from feral pigeons captured in Fortaleza, Brazil, from November 2014 to June 2015

\begin{tabular}{lc}
\hline \multicolumn{1}{c}{ Antimicrobial } & Resistance rates \\
\hline Azithromycin & $21.8 \%(24 / 110)$ \\
Tetracycline & $10.9 \%(12 / 110)$ \\
Sulfamethoxazole with trimethoprim & $8.1 \%(9 / 110)$ \\
Amoxicillin & $3.6 \%(4 / 110)$ \\
Chloramphenicol & $3.6 \%(4 / 110)$ \\
Cephalexin & $2.7 \%(3 / 110)$ \\
Ceftiofur & $2.7 \%(3 / 110)$ \\
Ciprofloxacin & $0.9 \%(1 / 110)$ \\
Polymyxin B & $0.9 \%(1 / 110)$ \\
Gentamycin & $0.9 \%(1 / 110)$ \\
Tobramycin & $0 \%(0 / 110)$ \\
Amoxicillin with clavulanic acid & $0 \%(0 / 110)$
\end{tabular}

Table 2. Antimicrobial resistance profiles of 31 Escherichia coli strains isolated from feral pigeons captured in Fortaleza, Brazil, from November 2014 to June 2015

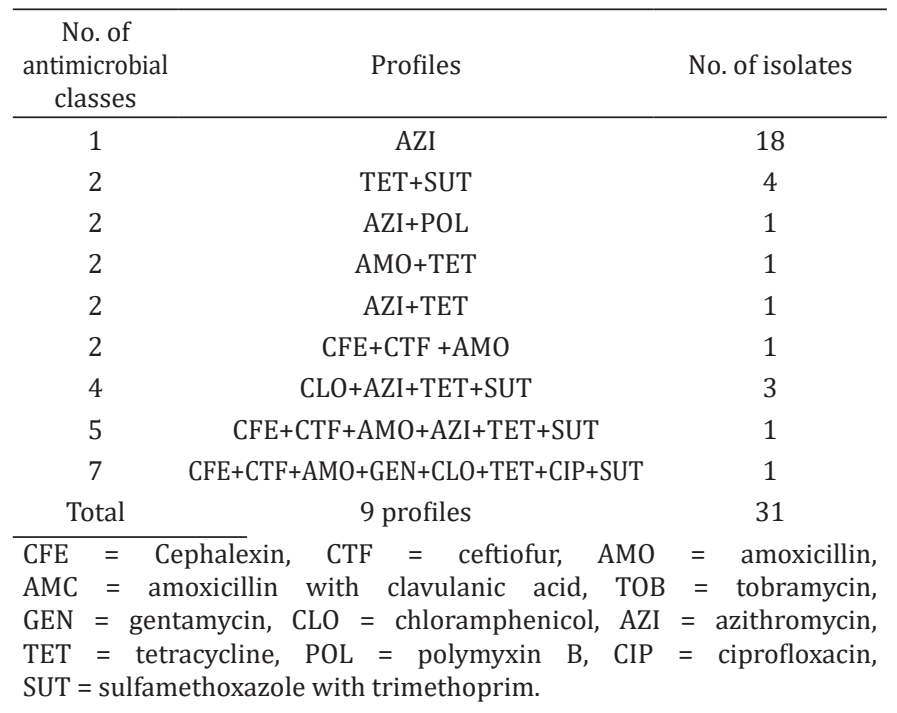

Diarrheagenic Escherichia coli. The eltB gene was identified in one isolate $(1 / 110 ; 0.91 \%)$, belonging to the ETEC pathotype, while the remaining genes were not detected.

\section{DISCUSSION}

Several techniques have been used over the centuries to capture wild birds, mostly for feeding and clothing. However, current interests for capturing wild birds are more diverse, often implicated as part of disease control programs, population regulation activities, wildlife management efforts, and research studies (Schemnitz 2005). In addition, animal welfare concerns implicate in a continuous search for techniques to capture wild birds without causing unnecessary suffering (FAO 2007). In this study, three techniques were used in different situations, two of which presented good results. However, the noose carpet technique led to occasional deaths and presented animal welfare implications.

A study performed in Juiz de Fora, Brazil, with one hundred fresh fecal samples collected in an urban environment revealed that $86 \%$ of samples were positive for Escherichia coli (Silva et al. 2009). However, this study showed a higher isolation rate $(97.58 \%)$, which could be explained by the different microbiological methodology. In that report, swabs were placed in saline and directly plated, while the pre-enrichment broth used in the present study may have promoted a better recovery of bacterial cells.

In general, antimicrobial resistance rates appear to vary greatly among E. coli strains isolated from pigeons depending on the location (Radimersky et al. 2010, Dutta et al. 2013b). However, in Brazil, low resistance rates have been reported in a pigeon population (Silva et al. 2009), which corroborates with the results in this study. This may indicate that, in Brazil these birds are not frequently in contact with antibiotics or resistant bacteria, as we can see in other countries in which resistant bacteria were isolated from pigeons (Radimersky et al. 2010, Dutta et al. 2013b). Despite the great variation in rates observed in different studies, resistance to some specific antimicrobial groups, such as tetracycline and sulfonamides, are commonly reported (Silva et al. 2009, Radimersky et al. 2010, Dutta et al. 2013b).

Low frequencies of diarrheagenic E. coli have been identified in feral pigeons (Morabito et al. 2001, Pedersen et al. 2006, Gargiulo et al. 2014). However, different pathotypes have been identified recently in Brazil and ETEC prevalence was 7.1\% (Silva et al. 2009). In this study, a single strain was identified as diarrheagenic, belonging to the ETEC pathotype. This result suggests that the studied population does not frequently host these microorganisms and appears to offer little risk to the public health, concerning these pathogens.

Several studies reported different isolation rates of Salmonella from feral pigeons, such as: $8 \%$ of pigeons in India, $13.3 \%$ in Egypt, $4.17 \%$ in Norway, $5.7 \%$ in Slovenia, and $7.94 \%$ in Brazil (Refsum et al. 2002, Dovč et al. 2004, Sousa et al. 2010, Dutta et al. 2013a, Osman et al. 2013). However, the isolation rate in this study was lower than all of the previously reported studies, which is an indication that the population of feral pigeons in Fortaleza have a low prevalence of this bacterium.

The link between poultry and salmonellosis in humans is well established and an outbreak have been reported in Brazil (De Almeida et al. 2015). In addition, there are several 
studies (Refsum et al. 2002, Dovč et al. 2004, Sousa et al. 2010, Dutta et al. 2013a, Osman et al. 2013) demonstrating the isolation of Salmonella strains from feral pigeons in different countries, including Brazil (De Sousa et al. 2010). Despite that, the public health risk that these animals pose of transmitting this pathogen may be overestimated due to the lack of reported cases of human salmonellosis originated from feral pigeons (Haag-Wackernagel \& Moch 2004). In fact, there is only a single reported case of human salmonellosis transmitted by a pigeon in recent years (Lacassin et al. 1995). Therefore, in this study public health risk may be considered low, despite the isolation of a Salmonella strain, which is an important human pathogen.

\section{CONCLUSIONS}

Captured feral pigeons of Fortaleza presented a low prevalence of Salmonella enterica and diarrheagenic Escherichia coli. Considering these pathogens, this study suggests a good health status and a low risk to the public health.

However, important multidrug resistance profiles were identified in the investigated isolates. In addition, the noose carpet technique did not present adequate results concerning animal welfare restrictions and it is not recommended for capturing feral pigeons.

\section{REFERENCES}

Almeida I.A.Z.C., Peresi J.T.M., Alves E.C., Marques D.F., Teixeira I.S.C., Silva S.I.L., Pigon S.R.F., Tiba M.R. \& Fernandes S.A. 2015. Salmonella Alachua: causative agent of a foodborne disease outbreak. Braz. J. Infect. Dis. 19(3):233-238. <http://dx.doi.org/10.1016/j.bjid.2014.12.006> <PMid:25661321>

CLSI 2014. Performance Standards for Antimicrobial Susceptibility Testing; Twenty-Fourth Informational Supplement. CLSI document M100-S24. Clinical and Laboratory Standards Institute, Wayne, USA.

Dovč A., Zorman-Rojs O., Vergles Rataj A., Bole-Hribovšek V., Krapež U. \& Dobeic M. 2004. Health status of free-living pigeons (Columba livia domestica) in the city of Ljubljana. Acta Vet. Hungarica 52(2):219-226. <http://dx.doi. org/10.1556/AVet.52.2004.2.10> <PMid:15168753>

Dutta P., Borah M., Sarmah R. \& Gangil R. 2013a. Isolation of Salmonella Typhimurium from pigeons (Columba livia) in Greater Guwahati, its histopathological impact and antibiogram. Comp. Clin. Pathol. 22(1):147150. <http://dx.doi.org/10.1007/s00580-012-1614-3>

Dutta P., Borah M., Sarmah R. \& Gangil R. 2013b. Isolation, histopathology and antibiogram of Escherichia coli from pigeons (Columba livia). Vet. World 6(2):91-94. <http://dx.doi.org/10.5455/vetworld.2013.91-94>

EFSA \& ECDC. 2016. The European Union summary report on antimicrobial resistance in zoonotic and indicator bacteria from humans, animals and food in 2014. EFSA J. 14(2):4380.

FAO 2007. Wild Birds and Avian Influenza: an introduction to applied field research and disease sampling techniques, p.13-32. In: Whitworth D., Newman S.H., Mundkur T. \& Harris P. (Eds), FAO Animal Production and Health Manual, No. 5. FAO, Rome.

Gargiulo A., Russo T.P., Schettini R., Mallardo K., Calabria M., Menna L.F., Raia P., Pagnini U., Caputo V., Fioretti A. \& Dipineto L. 2014. Occurrence of enteropathogenic bacteria in urban pigeons (Columba livia) in Italy.
Vector-Borne Zoonot Dis. 14(4):251-255. <http://dx.doi.org/10.1089/ vbz.2011.0943><PMid:24661012>

González-Acuña D., Silva G F., Moreno S L., Cerda L F., Donoso E S., Cabello C J. \& López M J. 2007. Detección de algunos agentes zoonóticos en la paloma doméstica (Columba livia) en la ciudad de Chillán, Chile. Revta Chilena Infect. 24(3):199-203. <http://dx.doi.org/10.4067/S0716-10182007000300004> $<$ PMid:17554438>

Grimont P.A.D. \& Weill F.X. 2007. Antigenic formulae of the Salmonella serovars, p.6-9. In: Ibid. (Eds), WHO Collaborating Centre for Reference and Research on Salmonella. 9th ed. OCLC ResearchWorks Terms and Conditions, Paris.

Haag-Wackernagel D. \& Moch H. 2004. Health hazards posed by feral pigeons. J. Infect. 48(4):307-313.<http://dx.doi.org/10.1016/j.jinf.2003.11.001> <PMid:15066331>

Lacassin F., Mino J.C., Benoit C., Perronne C., Leport C. \& Vildé J.L. 1995. A propos d'un cas de salmonellose aviaire [A case of avian salmonellosis]. Revta Med. Intern. 16(1):77-78. <http://dx.doi.org/10.1016/02488663(96)80671-0>

Morabito S., Dell'omo G., Agrimi U., Schmidt H., Karch H., Cheasty T. \& Caprioli A. 2001. Detection and characterization of Shiga toxin-producing Escherichia coli in pigeons. Vet. Microbiol. 82(3):275-283.<http://dx.doi. org/10.1016/S0378-1135(01)00393-5><PMid:11470548>

Osman K.M., Mehrez M., Erfan A.M. \& Nayerah A. 2013. A. Salmonella enterica isolated from pigeon (Columba livia) in Egypt. Foodborne Pathogens Dis. 10(5):481-483.<http://dx.doi.org/10.1089/fpd.2012.1347><PMid:23531124>

Pedersen K., Clark L., Andelt W.F. \& Salman M.D. 2006. Prevalence of Shiga toxin-producing Escherichia coli and Salmonella enterica in rock pigeons captured in Fort Collins, Colorado. J. Wildl. Dis. 42(1):46-55. <http://dx.doi. org/10.7589/0090-3558-42.1.46><PMid:16699148>

Radimersky T., Frolkova P., Janoszowska D., Dolejska M., Svec P., Roubalova E., Cikova P., Cizek A. \& Literak I. 2010. Antibiotic resistance in faecal bacteria (Escherichia coli, Enterococcus spp.) in feral pigeons. J. Appl. Microbiol. 109(5):1687-1695. <PMid:20602656>

Refsum T., Handeland K., Baggesen D.L., Holstad G. \& Kapperud G. 2002. Salmonellae in avian wildlife in Norway from 1969 to 2000. Appl. Env. Microbiol. 68(11):5595-5599. <http://dx.doi.org/10.1128/AEM.68.11.55955599.2002><PMid:12406754>

Schemnitz S.D. 2005. Capturing and handling wild animals, p.239-285. In: C.E. Braun (Ed.), Techniques for Wildlife Investigations and Management. The Wildlife Society, Bethesda, USA.

Silva V.L., Nicoli J.R., Nascimento T.C. \& Diniz C.G. 2009. Diarrheagenic Escherichia coli strains recovered from urban pigeons (Columba livia) in Brazil and their antimicrobial susceptibility patterns. Curr. Microbiol. 59(3):302-308. <http://dx.doi.org/10.1007/s00284-009-9434-7> <PMid:19504156>

Sousa E., Berchieri Junior A., Pinto A.A., Machado R.Z., Carrasco A.O.T., Marciano J.A. \& Werther K. 2010. Prevalence of Salmonella spp. antibodies to Toxoplasma gondii, and Newcastle disease virus in feral pigeons (Columba livia) in the city of Jaboticabal, Brazil. J. Zoo Wildl. Med. 41(4):603-607. <http://dx.doi.org/10.1638/2008-0166.1><PMid:21370639>

Taniuchi M., Walters C.C., Gratz J., Maro A., Kumburu H., Serichantalergs O., Sethabutr O., Bodhidatta L., Kibiki G., Toney D.M., Berkeley L., Nataro J.P. \& Houpt E.R. 2012. Development of a multiplex polymerase chain reaction assay for diarrheagenic Escherichia coli and Shigella spp. and its evaluation on colonies, culture broths, and stool. Diagn. Microbiol. Infect. Dis. 73(2):121-128. <http://dx.doi.org/10.1016/j.diagmicrobio.2012.03.008> $<$ PMid:22541788> 